\title{
On the Present Situation and Countermeasures of Teaching Archives Management in Colleges
}

\author{
Ying-xin RAO \\ Changshu Institute of Technology \\ School of Electric and Automatic Engineering \\ Changshu, Jiangsu Province, China \\ raoyingxin@163.com
}

\begin{abstract}
With the development of higher education in our country and the acceleration of the construction of informationization of the colleges, the requirements for the management of teaching archives in colleges are also increasing. This paper analyzes the characteristics and existing problems of the current teaching archives management in colleges, and puts forward relevant measures from four aspects: teaching archives construction, service mechanism, team building, and standardization and evaluation mechanism. In order to further improve the construction of teaching archives the relevant reference.
\end{abstract}

Keywords-teaching archives management; the status quo; countermeasures

\section{INTRODUCTION}

In recent years, with the deepening of the reform of the education system, the mode of higher education in our country has undergone major changes. The teaching direction of higher education has gradually changed from the original elite education to the popularization direction. As a teaching link in the work center of colleges and universities, it is complicated with the diversification of teaching forms and curriculum patterns. This makes the types of teaching files continue to increase, the contents of the file has become increasingly complex and diversified, and so the teaching management of colleges and universities put forward higher requirements. Archives management in colleges is an important criterion for measuring the quality and management level of school education and it is an important content of various assessment works in schools. Is to promote and improve the level of teaching management is the school's valuable wealth and intellectual resources. It is of great practical significance and historical significance to comprehensively promote the improvement of teaching work and improve the quality of running a school in the management of teaching archives and accumulate the real historical materials of teaching activities.

\section{THE CHARACTERISTICS OF TEACHING ARCHIVES}

\section{Decentralized and systematic}

The source of teaching files in colleges is more decentralized, in addition to the higher authorities and the various documents issued by the school, teaching units (departments) of the internal documents, there are first-line teachers and students from the management of a large number of text materials, related video, $\mathrm{CD}$, courseware, photos and other information. Most of these 
materials are scattered in the various teaching departments and teachers, students or managers in the hands, resulting in decentralized teaching files. There are relatively fixed educational modes and teaching rules in the various colleges and universities, and the students have a relatively complete set of teaching documents, including the students' enrollment, training and graduation, and reflect the teaching files the systematic. The decentralization and systemativeness of the source of the teaching archives make it difficult to document the archives.

\section{Cyclical and dynamic}

College teaching activities are a kind of cyclical activities aiming at the cultivation of students' academic education. Each student's training process is a teaching cycle, and the teaching files are characterized by cyclical characteristics. However, the teaching documents in the teaching process continue to produce, the corresponding materials are divided into semesters, with school year or divided into natural years, this time teaching files show dynamic random characteristics. The cyclical and dynamic nature of the teaching file determines that the file management must form its own unique management model.

\section{Professional and complex}

College teaching archives of professional, including the natural sciences, social sciences and emerging edge science, as well as enrollment plans, resource allocation, teaching management, student management and so on. The scope is broad and complex.

\section{THE PROBLE,S EXISTING IN CURRENT TEACHING ARCHIVES MANAGEMENT WORK}

The teaching archives of colleges and universities are the historical records of the teaching work in colleges and the cornerstone of the new teaching ideas and ideas in the development of colleges and universities. It plays an important role in comprehensively promoting the improvement of teaching work and improving the quality of running schools. However, due to various reasons, at present our country in the teaching archives management work still has some problems, mainly in:

\section{A. Teaching files lack openness}

The traditional teaching archives management methods are often archiving, pay attention to preservation and ignore its application value, the lack of openness. Teaching archives management is often carried out in a semi-closed state and its service model is a collection of - save - borrow the main, reflecting the teaching file information development and utilization of lack of knowledge. Through the file catalog, index to reflect the file information, the need to manually check the file to pass information, service forms presented passive, lack of multi-channel, multi-level integrated service functions, did not form a file manager and information needs between the benign interaction.

\section{B. Teaching file management is not rigorous}

Teaching archives management work has a certain degree of planning and purpose, teaching archives management involving enrollment, teaching plans, scientific research arrangements, school management and other aspects of a variety of literature, is a post hoc behavior, is a teaching behavior after the sorting Activities, when a plan or a specific goal to achieve, the resulting archives are often not taken seriously, easily lead to the loss of archival information.

\section{Teaching files classified chaos}

Many colleges and universities do not have a good implementation of the principles of unified management of teaching files, the functional departments and secondary school teaching documents, file management of their own way, the lack of effective 
coordination mechanism, the emergence of documents and archiving two aspects of out of control, resulting in file management confusion. The phenomenon of inconsistencies between the various departments have occurred, some teaching records are beginning and end, the lack of integrity.

\section{Management professional quality is low}

Most of the staff of the teaching management of the staff of non-full-time administrator, but not the archives of professional, these people lack a keen sense of occupational sense of smell, strong file value identification and management skills, faculty records change frequently, file management work unfamiliar Phenomenon is more common, business ability is not strong. Some people engaged in file management work, that the file management works in colleges without status, a sense of accomplishment. Under the action of this kind of thought, some people will work on the surface; there is no in-depth study and research to explore the management of teaching archives, leading to the overall quality of teaching archives generally low.

\section{THE SCIENTIFIC MANAGEMENT OF TEACHING ARCHIVES AND EFFECTIVE USE OF THE STRATEGY}

\section{A. Teaching archives construction.}

In view of the teaching characteristics, the teaching archives work into the teaching plan, planning, into the positions of managers at all levels, into the assessment of teaching quality and management standards. In the teaching file management work, the establishment of a set of teaching management system for the school, that is, to develop a clear teaching - file target management standards, file managers in the usual work to pay great attention to the collection and accumulation of teaching files, Value of the teaching documents. Teaching tasks, teaching materials, teaching results and review, acceptance of archival material synchronization; graduation distribution, reporting and reviewing the quality of teaching materials, teaching materials, teaching materials, teaching materials, teaching materials, teaching materials, The examination promotion is accompanied by an archival certificate issued by the archives department.

\section{B. Service mechanism.}

Archives personnel to explore the content of teaching files, and teaching archives information analysis, research, screening, processing, editing, the original, decentralized, fragmented static file into a finger, system, live file information, timely , Accurately delivered out to the school teachers and students and social use. Archivists should be based on the use of demand for vertical extension, from a literature, the second literature to the three literature processing development, the formation of systems, authority, deep level of information, so that it has practicality, timeliness. The research materials focus on those important, the use of frequent teaching files. Scientific and systematic work of editing and editing archives, so that the file can give full play to its use value, to write school history, professional adjustment, student graduation distribution, rich teaching reform activities to provide a favorable basis.

\section{Team building. Standardization and evaluation mechanism.}

1) Evaluation mechanism. Focus on the quality of teaching archives evaluation; you can keep abreast of the file management work in the weak links, easy to improve. User feedback function can make teaching files from the user's point of view of their own deficiencies, and constantly improve them. Can learn from and absorb some advanced evaluation mechanism, set up for the school teaching file management feedback function. Archives management departments through briefing, campus network, etc., to the 
departments, teachers and students timely feedback teaching archives information, to collect all departments in time to use the teaching file feedback, and constantly adjust and improve the teaching file management. But also adhere to the scientific evaluation of the combination of qualitative and quantitative principles, the entire service process in the development of a comprehensive evaluation of the various indicators.

2) Standardization. The teaching archives material should unify the number, the platoon, enter the library. For the collection of teaching materials, to carry out scientific classification, pricing, volume, entry, the implementation of a unified file number, the preparation of teaching files directory and a variety of search tools, including catalogs, thematic catalogs and so on. Keep the rack and keep it in storage.

\section{CONCLUSION}

With the deepening of higher education reform, the state will take various forms to evaluate the level of running a university, and the level of teaching archives management and utilization is one of the important symbols of the university. How to coordinate the work relationship between the archives department and other business departments (archives department) in the system, and standardize the standardization of teaching files, and also need the archives workers and scholars to further study and solve. Technological progress makes it possible for scientific management and effective use of university teaching archives, and it is also necessary for archivists and relevant personnel to think deeply about feasible solutions.

\section{REFERENCES}

As a teaching link in the work center of colleges and universities, it is complicated with the diversification of teaching forms and curriculum patterns[1].

There are relatively fixed educational modes and teaching rules in the various colleges and universities, and the students have a relatively complete set of teaching documents, including the students' enrollment, training and graduation, and reflect the teaching files the systematic[2].

College teaching activities are a kind of cyclical activities aiming at the cultivation of students' academic education[3]. Each student's training process is a teaching cycle, and the teaching files are characterized by cyclical characteristics[4].

The traditional teaching archives management methods are often archiving, pay attention to preservation and ignore its application value, the lack of openness. Teaching archives management is often carried out in a semi-closed state and its service model is a collection of - save - borrow the main, reflecting the teaching file information development and utilization of lack of knowledge[5][6].

[1] Sun Shuyang, Ding Zhimin. Archives computer management course [M]. Beijing: China People's University Press, 1999.

[2] Shi Yajun. Problems and Countermeasures of Internal Management System Reform in Chinese Universities [J] .Journal of Teaching and Research, 2000, (4)

[3] Li Hua. Thinking about the innovation of university file management [J]. Journal of Jiamusi University Social Sciences .2003, 21 (4)

[4] Liu Fang, Zhou Jinyang. Reflections on the management of teaching archives in colleges [J]. Journal of Shanxi Provincial Committee Party School, 2006, 29 (3)

[5] Zheng Li. Feasibility of Constructing Networked Archives in colleges [J] .Lantai World, 2005 (7)

[6] Zhan Guisheng. College teaching archives construction should pay attention to the three aspects [J]. Lantai World, 2007 (5) 